\title{
RESENHA
}

\section{RESENHA DO LIVRO MEMÓRIA COLETIVA E IDENTIDADE NACIONAL, MIRYAM SANTOS}

\author{
POR MARIANA MOREIRA
}

PALAVRAS-CHAVE Identidade Memória

Esquecimento
KEY WORDS Identity

Memory $\underline{\text { Forgetfulness }}$

A presente resenha aborda o livro "Memória Coletiva e Identidade Nacional", de autoria de Myrian Sepúlveda dos Santos. Importante pesquisadora de temas como memória, identidade, práticas políticas, culturais e relações raciais, obteve seu título de doutora em Sociologia pela New School for Reserch de Nova Iorque e desenvolveu pesquisas em pós-doutorado no Centro de Estudos Latino-Americanos da University of Cambridge; no Centro de Pesquisa sobre Relações Sociais da Université de Paris V e no Centro de Estudos Sociais da Universidade de Coimbra. Atualmente é professora associada da Universidade do Estado do Rio de Janeiro e coordena o Grupo de Pesquisa Cultura e Poder, registrado no CNPQ Arte, e o museu Afrodigital. Suas análises abordam teorias de nomes de grande relevância para os Estudos Culturais como Karl Marx, Walter Benjamin, Michel Foucault, Maurice Halbwach, Stuart Hall entre outros.

Em "Memória Coletiva e Identidade Nacional" a autora analisa criticamente sua própria produção nos últimos 20 anos e traz reflexões sobre como e porque se dão os processos de lembrar e esquecer e sobre a relação entre identidade nacional e memória coletiva. A obra é composta por 10 capítulos divididos em duas partes: "Memória e Poder" e "Identidade e Cultura".

A primeira parte do livro traz discussões teóricas importantes sobre temas como memória individual e coletiva, memória voluntária e involuntária, história, tradição e esquecimento. Começa com a investigação de impasses entre memória e esquecimento no que diz respeito à preservação e divulgação de arquivos de guerras, conflitos e período de opressão política. Santos diz que narrativas históricas presidem a organização de arquivos, coleções e museus no intuito de preservar o que já passou, mas ainda assim não proporcionam uma verdade absoluta. Ao analisar as teorias de memória coletiva de Halbwachs e Nora, conclui 
que há diversos caminhos de acesso ao passado e que todos eles se deparam com tensões, conflitos e disputas. O fundamental, para ela, é perceber que não há nada de natural na reconstrução do que passou. A lembrança está vinculada àqueles que têm o poder, pois estes são os que decidem quais narrativas deverão ser lembradas.

Eficazes instrumentos de poder, a memória e o esquecimento têm sido utilizados por inúmeros governos, totalitários ou democráticos, com objetivo de alcance do controle político. Em casos de situações de extrema agressividade e violência, Santos observa a inviabilidade de resposta das vítimas, que se tornam incapazes de utilizar sua memória de forma seletiva. Pollak (1989) concorda ao dizer que "as lembranças proibidas, indizíveis ou vergonhosas são zelosamente guardadas em estruturas de comunicação informal e passam despercebidas pela sociedade englobante".

Assim, o papel de arquivos referentes a este tipo de evento não deve ser o de explicar o que não pode ser explicado, mas de manter viva a memória do que não pode se repetir. Nesse contexto, Santos ressalta a necessidade de encontrar o equilíbrio entre a obsessão pelo passado e a imposição do esquecimento.

Ainda na primeira parte do livro, Santos apresenta um texto que escreveu em 2003 enquanto fazia seu trabalho de campo na Vila de Dois Rios, na Ilha Grande. Através de uma bem efetuada análise de narrativas sobre o assassinato de um morador, a autora mostra como as diferentes versões da história relacionam-se às memórias coletivas dos diversos grupos existentes (policiais militares, guardas penitenciários, moradores, ex-presidiários) e que algumas das memórias podem romper com o quadro social em que se inserem. A ilha trazia uma história de crimes e os órgãos oficiais não tinham interesse em preservar sua memória. Seu estudo é um bom exemplo de preocupação com a preservação daquilo que se poia apenas no testemunho oral, podendo se perder a qualquer momento. Como coloca Pollak (1989), "ao privilegiar a história dos excluídos, dos marginalizados e das minorias, a história oral ressaltou a importância das memórias subterrâneas que, como parte das culturas minoritárias dominadas, se opõem à memória oficial”.

Na segunda parte da obra, que tem como objetivo analisar a relação entre memória coletiva e identidade nacional, a autora se debruça sobre os trabalhos de alguns autores pós-colonialistas que denunciam a relação entre construção simbólica e poder e a consequente exclusão de grande parte da população da vida política. Ao investigar as representações da população afrodescendente, observa que instituições oficiais como arquivos, bibliotecas e museus a mostra de forma desvantajosa, silenciando suas lutas, criando estereótipos e a vitimizando.

Dentro do contexto de memória e identidade negra, Santos estuda dois filmes que foram produzidos a partir da peça Orfeu da Conceição, de Vinícius de Moraes, cujo tema universal é trabalhado dentro do contexto do carnaval do Rio de Janeiro, contrapondo a arte à realidade trágica da vida nas favelas. $\mathrm{O}$ primeiro filme é gravado anos 1950 e não mostra conflitos sociais ou práticas de discriminação racial, representando a pobreza de forma romântica. Já na segunda versão, que data 
dos anos 90, há uma atenção maior à retratação da realidade social da pobreza e violência nas favelas, do mundo urbano e das tecnologias. A autora conclui que, se é ultrajante descrever a cidade apenas por meio de imagens de festividade, alegria, dança e música, é também ultrajante descreve-la apenas ressaltando a violência. Portanto, diz que ambos os filmes apresentam interpretações restritas de fenômenos sociais complexos e acabam oferecendo um estereotipo de país subdesenvolvido.

No último capitulo da obra, a autora analisa a construção da identidade nacional brasileira entre 1930 e 2010 tendo em conta as políticas públicas culturais e suportes à memória. A partir da tomada de poder por Getúlio Vargas na década de 30, o Brasil implantou uma política cultural que visava à construção de uma identidade nacional e popular. A intervenção do Estado na cultura foi retomada durante o regime militar que usou como instrumento a segurança nacional e o forte investimento na indústria cultural. Com a queda deste regime, os próximos governos, que apresentavam características neoliberais, retraíram fortemente o investimento em politicas culturais. Em seguida, o governo petista retomou o intervencionismo, substituindo o imaginário unificado da nação por um que valorize as diferenças éticas e regionais.

"Memória Coletiva e Identidade Nacional" é denso e mostra-se uma leitura importante para quem inicia os estudos de memória e identidade, pois compila didaticamente o pensamento de diversos estudiosos. Frente à diversidade de abordagens, a autora as compara cuidadosamente e leva em conta as contribuições e limites de cada uma, concluindo que as formas de lidar com o passado sempre envolvem interesse, poder e exclusão e que a memória deve ser vista como algo mutável, suscetível a transformações de fenômenos, conceitos e percepções.

Apesar de demonstrar diversas possibilidades de reconstrução do passado, a obra não apresenta o intuito de esgotá-las. Ao contrário, incita o debate, dando em cada capítulo subsídios para que a problemática siga sendo analisada por diferentes ângulos.

\section{bibliografia}

ARAÚJO, Maria Paula Nascimento e Myrian Sepúlveda dos Santos. 2007. História, memória e esquecimento: implicações políticas. Revista Crítica de Ciências Sociais,79:95 -111

HALL, Stuart. A Identidade Cultural na Pós Modernidade. Rio de Janeiro: DP\&A, 2006.

ORTIZ, Renato. Cultura Brasileira e Identidade Nacional. São Paulo, Editora Brasiliense, 1985. 
POLLAK, Michel. Memória, Esquecimento e Silêncio. Estudos Históricos. Rio de Janeiro, vol. 2, n. 3, 1989.

POLLAK, Michael. Memória e Identidade Social. Estudos Históricos. Rio de Janeiro, vol. 5, n. 10, 1992. 